\title{
Risk assessment of pet-traded decapod crustaceans in the Republic of Kazakhstan, the leading country in Central Asia
}

\author{
Talgat Uderbayev ${ }^{1, *}$, Jiř́ Patoka ${ }^{2}$, Ruslan Beisembayev ${ }^{1}$, Miloslav Petrtýl ${ }^{2}$, Martin Bláha ${ }^{3}$ and \\ Antonín Kouba ${ }^{3}$ \\ ${ }^{1}$ Kazakh Research Institute of Fishery, Suyunbai Avenue 89, 050016 Almaty, Kazakhstan \\ ${ }^{2}$ Department of Zoology and Fisheries, Faculty of Agrobiology, Food and Natural Resources, Czech University of Life \\ Sciences Prague, Kamýcká 129, 16000 Prague - Suchdol, Czech Republic \\ ${ }^{3}$ South Bohemian Research Center of Aquaculture and Biodiversity of Hydrocenoses, Faculty of Fisheries and Protection of Waters, \\ University of South Bohemia in České Budějovice, Zátiší 728/II, 38925 Vodnany, Czech Republic
}

\begin{abstract}
The pet trade with decapod crustaceans has been considered one of the main pathway of introduction of these animals worldwide. As the leading markets in this regards are the Czech Republic, Germany and the USA. Central Asia is not perceived as an important market with ornamental decapod crustaceans. Despite this assumption, we found at least 16 species of freshwater shrimp, crayfish and crab species pet-traded in the Republic of Kazakhstan, the largest country in this region. Considering computed risk assessment, the origin of particular species, their availability on the market, the probability of establishment and further aspects, we identified two crayfish Procambarus clarkii and Procambarus fallax f. virginalis being the seriously hazardous taxa with high potential to threaten native crayfish species as well as inhabited ecosystems. To prevent their introductions and to minimize the risks of mentioned species, similarly as in the case of European Union, we recommend the total ban of import, trade and keeping of these high-risk taxa within Central Asia.
\end{abstract}

Keywords: biological invasion / climate matching / introduction pathway / Procambarus clarkii / Procambarus fallax f. virginalis

Résumé - Évaluation des risques du commerce des crustacés décapodes pour l'aquariophilie en République du Kazakhstan, premier pays d'Asie centrale. Le commerce des animaux de compagnie avec des crustacés décapodes a été considéré comme l'un des principaux moyens d'introduction de ces animaux dans le monde entier. Comme les principaux marchés à cet égard sont la République tchèque, l'Allemagne et les États-Unis, l'Asie centrale n'est pas perçue comme un marché important des crustacés décapodes ornementaux. Malgré cette hypothèse, nous avons trouvé au moins 16 espèces de crevettes, d'écrevisses et de crabes d'eau douce commercialisées dans la République du Kazakhstan, le plus grand pays de cette région. Compte tenu de l'évaluation des risques calculés, de l'origine d'espèces particulières, de leur disponibilité sur le marché, de la probabilité d'établissement et d'autres aspects, nous avons identifié deux écrevisses Procambarus clarkii et Procambarus fallax f. virginalis étant les taxons gravement dangereux avec un risque élevé de menacer les espèces d'écrevisses natives ainsi que les écosystèmes habités. Pour éviter leur introduction et minimiser les risques des espèces mentionnées, de même que dans le cas de l'Union européenne, nous recommandons l'interdiction totale d'importer, de commercialiser et de conserver ces taxons à haut risque en Asie centrale.

Mots-clés : invasion biologique / adaptation climatique / voie d'introduction / Procambarus clarkii / Procambarus fallax f. virginalis

\section{Introduction}

The international pet industry encompasses numerous freshwater and marine species (Tlusty et al., 2013). In contrast to the long history of trade and keeping of tremendously

\footnotetext{
${ }^{*}$ Corresponding author: talga_93@mail.ru
}

popular freshwater fish and molluscs, the pet trade with freshwater ornamental decapod crustaceans including crayfish, shrimps and crabs has started rather late, in the mid-1990s (Scholtz et al., 2003; Chucholl, 2013; Patoka et al., 2016a).

Globally, we can found numerous examples of humanmediated introductions of non-native ornamental decapod crustaceans (Magalhães et al., 2005; Kawai et al., 2009; Klotz 
et al., 2013; Vojkovská et al., 2014; Lipták et al., 2016; Patoka et al., 2016d). Negative consequences such as out-competition with native species, disease spread, food web and habitat alternation, and incidental fauna introduction are widely discussed (Duggan, 2010; Gherardi et al., 2011; Chucholl and Wendler, 2016; Patoka et al., 2016a; Souty-Grosset et al., 2016). Although pet trade has been considered one of the most important sources of non-native species (Padilla and Williams, 2004; Duggan, 2010), risk assessment of decapod crustaceans introduced via this pathway had been marginalized for a long time. The situation began to change in recent years (see Soes and Koese, 2010; Chucholl, 2013; Faulkes, 2014; Papavlasopoulou et al., 2014; Patoka et al., 2014a; Mazza et al., 2015; Kotovska et al., 2016). Since mitigation and eradication are difficult and mostly impossible when non-native species become established (Aquiloni et al., 2009), the importance of prevention is obvious (Souty-Grosset et al., 2016). In this regards, the climatic modelling and risk assessment are processed by various tools to high-risk species identification.

Pet-traded freshwater animals and ornamental plants are not kept exclusively in indoor tanks, but they are also frequently released into the garden and urban ponds (Hassall, 2014; Patoka et al., 2016b, c). Despite the unexceptional illegality of this act, it is also true for freshwater decapod crustaceans (Peay, 2009; Patoka et al., 2014b; Novitsky and Son, 2016). Leading markets with ornamental freshwater decapod crustaceans globally are the Czech Republic (Patoka et al., 2015), Germany (Chucholl, 2013; Chucholl and Wendler, 2016) and the USA (Faulkes, 2015b), followed by several other countries such Brazil (Magalhães et al., 2005), Greece (Papavlasopoulou et al., 2014), Russia (Vodovsky et al., 2017), Slovakia (Lipták and Vitázková, 2015), Turkey (Turkmen and Karadal, 2012) and Ukraine (Kotovska et al., 2016).

Within the meaning of pet trade, Central Asia is not perceived as an important market with freshwater decapod crustaceans. The economically dominant country of this region is the Republic of Kazakhstan (further referred as Kazakhstan) (Takenov et al., 2004; Pomfret, 2006). With 2.72 million $\mathrm{km}^{2}$ of land it is the world's largest landlocked country and its territory forms eight internal-drainage basins, none of which have a direct outflow into an ocean (Takenov et al., 2004).

Especially crayfish are perceived as animals with great and not fully exploited potential in aquaculture production in Kazakhstan. Although the taxonomy of Eastern European and Central Asian crayfish taxa are to a certain degree still nonsettled, the usually accepted state is that native Kazakhstan decapods are represented by two crayfish species occurring in western part of the country: Astacus leptodactylus and Astacus pachypus (Malinovskaia, 1984; Kirichenko et al., 2013; Kouba et al., 2014). Even if data from the eastern part of the country are almost lacking, some fragmentary information appears to indicate that crayfish also live here, at least in Balkhash Lake where are preyed by invasive fish species (Mamilov, 2015). No relevant information about the origin of these animals are available, but local people are convinced that the crayfish were introduced from Russia (Isaev and Karpova, 1989).

Furthermore, there are known two non-native decapod species currently occurring in Kazakhstan waterbodies: shrimps Palaemon modestus and Macrobrachium nipponense. Freshwater shrimp $P$. modestus native to eastern Asia was found established in the Ili River, flowing to Balkhash Lake, Almaty region, south-eastern Kazakhstan (De Grave and Mann, 2012). In this species, larval development is shortened as an adaptation to freshwater environment and thus there is no barrier to its spreading within landlocked regions (Kwon and Uno, 1968). The occurrence of $M$. nipponense native to China, Japan, Korea, Myanmar, Taiwan and Vietnam (De Grave and Ghane, 2006) was recorded in the Kapchagay Reservoir, a main dam on the Ili River (Alekhnovich and Kulesh, 2001). This species is highly adaptable under different environmental conditions and it can survive in freshwater for its entire life cycle (Mashiko, 1990). Although the introduction pathways related with both species in Kazakhstan remain rather unclear, De Grave and Ghane (2006), Mirabdullaev and Niyazov (2005) and De Grave and Mann (2012) suggested as the most probable the intentional introduction for consumption purposes or accidental escapes from aquaculture or ornamental stocks.

Although nothing is known about pet industry development in Kazakhstan, based on the aforementioned note, we hypothesised that the overlooked pet trade with decapod crustaceans exists in the country. Hence the objectives of the present study are: (i) the survey of market and compilation of the list of pet-traded decapods, and (ii) identification of potentially invasive species and assessment of related environmental risks.

\section{Material and methods}

\subsection{Data collection}

Information about pet-traded species of decapod crustaceans and their availability on Kazakhstan market were obtained over a period of May and October 2016. Altogether, we interviewed four wholesalers, five pet shop owners, two online shops and two local crayfish breeders. Two local pet bazaars (places where people can sell or change pets) were also visited. Collected records were subsequently clarified during personal visits and/or provided photo-documentation and misnomers as well as alternative trade names were eliminated.

\subsection{Availability on market}

Availability on market was evaluated for each species according to Chucholl (2013) using the following criteria: (i) "very rare" species available only for a short period and in low quantities; (ii) "rare" species available occasionally in low quantities; (iii) "common" species available frequently in low quantities; and (iv) "very common" species always available in high quantities. Even if this method is to a certain degree heuristic, it is useful for a rough estimate of species availability on market (Kotovska et al., 2016).

\subsection{Climate match}

Climatic conditions used for analysis of probability of survival were represented in our analysis by temperature during the coldest quarter of the year as a variable. The climate match between source and target area was compared using the Climatch tool (v.1.0; Invasive Animals Cooperative Research Centre, Bureau of Rural Sciences, http://data. daff.gov.au:8080/Climatch/climatch.jsp); we opted Euclidean 
T. Uderbayev et al.: Knowl. Manag. Aquat. Ecosyst. 2017, 418, 30

Table 1. List of pet-traded species of decapod crustaceans and their families, availability on market (VC, very common; C, common; R, rare; VR, very rare), potential invasiveness (FI-ISK score), risk category (FI-ISK category), nursery environment required for larval or juvenile development, environment for adult individuals (B, brackish water; F, freshwater), and native distribution (AF, Africa; AU, Australia; EA, East Asia; J, Japanese Archipelago; NA, North America; NG, New Guinea; SEA, South-eastern Asia).

\begin{tabular}{|c|c|c|c|c|c|c|c|}
\hline \multirow[t]{2}{*}{ Species } & \multirow[t]{2}{*}{ Family } & \multirow[t]{2}{*}{ Availability } & \multicolumn{2}{|c|}{ FI-ISK } & \multirow{2}{*}{$\begin{array}{l}\text { Nursery } \\
\text { environment }\end{array}$} & \multirow{2}{*}{$\begin{array}{l}\text { Adulthood } \\
\text { environment }\end{array}$} & \multirow{2}{*}{$\begin{array}{l}\text { Native } \\
\text { distribution }\end{array}$} \\
\hline & & & $\overline{\text { Score }}$ & $\overline{\text { Category }}$ & & & \\
\hline \multicolumn{8}{|l|}{ Shrimps } \\
\hline Atya gabonensis & Atyidae & $\mathrm{C}$ & 4 & Medium & $\mathrm{B}$ & $\mathrm{F}$ & $\mathrm{AF}$ \\
\hline Atyopsis moluccensis & Atyidae & $\mathrm{C}$ & 3 & Medium & $\mathrm{B}$ & $\mathrm{F}$ & SEA \\
\hline Caridina babaulti & Atyidae & $\mathrm{R}$ & -2 & Low & $\mathrm{F}$ & $\mathrm{F}$ & SA \\
\hline Caridina cantonensis & Atyidae & $\mathrm{VC}$ & -2 & Low & $\mathrm{F}$ & $\mathrm{F}$ & SEA \\
\hline Caridina multidentata & Atyidae & $\mathrm{VC}$ & 1 & Medium & $\mathrm{B}$ & $\mathrm{F}$ & $\mathrm{EA}, \mathrm{J}$ \\
\hline Caridina sp. Sulawesi & Atyidae & VR & $\mathrm{NE}^{*}$ & & $\mathrm{~F}$ & $\mathrm{~F}$ & SEA \\
\hline Macrobrachium nipponense & Palaemonidae & $\mathrm{R}$ & 14 & Medium & $\mathrm{F}, \mathrm{B}$ & $\mathrm{F}$ & EA, SEA, J \\
\hline Macrobrachium sp. & Palaemonidae & $\mathrm{R}$ & $\mathrm{NE}^{*}$ & & $?$ & $\mathrm{~F}$ & EA \\
\hline Neocaridina heteropoda & Atyidae & $\mathrm{VC}$ & 5 & Medium & $\mathrm{F}$ & $\mathrm{F}$ & $\mathrm{EA}, \mathrm{J}$ \\
\hline Neocaridina zhangjiajiensis & Atyidae & $\mathrm{R}$ & 0 & Medium & $\mathrm{F}$ & $\mathrm{F}$ & EA \\
\hline Palaemon modestus & Palaemonidae & $\mathrm{R}$ & 10 & Medium & $\mathrm{F}$ & $\mathrm{F}$ & EA \\
\hline \multicolumn{8}{|l|}{ Crayfish } \\
\hline Cherax destructor & Parastacidae & $\mathrm{R}$ & 20 & High & $\mathrm{F}$ & $\mathrm{F}$ & $\mathrm{AU}$ \\
\hline Cherax quadricarinatus & Parastacidae & $\mathrm{R}$ & 5 & Medium & $\mathrm{F}$ & $\mathrm{F}$ & $\mathrm{AU}, \mathrm{NG}$ \\
\hline Procambarus clarkii & Cambaridae & $\mathrm{R}$ & 27 & High & $\mathrm{F}$ & $\mathrm{F}$ & NA \\
\hline Procambarus fallax $\mathrm{f}$. virginalis & Cambaridae & $\mathrm{C}$ & 30 & High & $\mathrm{F}$ & $\mathrm{F}$ & $\mathrm{NA}^{* *}$ \\
\hline \multicolumn{8}{|l|}{ Crabs } \\
\hline Potamon potamios & Potamidae & VR & 8 & Medium & $\mathrm{F}$ & $\mathrm{F}$ & $\mathrm{NE}$ \\
\hline
\end{tabular}

* NE, not evaluated due to uncertain species identification.

** Native occurrence is not yet known.

algorithm. This tool was used in previous studies focusing decapod crustaceans (e.g. Chucholl, 2013; Patoka et al., 2014a; Kotovska et al., 2016). We used region of the native geographic range of evaluated species as the source area; in the case of marbled crayfish Procambarus fallax f. virginalis, which native occurrence is not yet known, the source region was taken in accordance with Chucholl (2014) as validated European localities with its established populations. The target area was defined as the territory of Kazakhstan containing 341 climatic stations from the database of the WorldClim (Hijmans et al., 2005). Where the climate match between the source area and the climatic station in the target area reached score $\geq 7.0$, this was interpreted as there is no environmental barrier to the survival of evaluated species.

\subsection{Risk assessment}

To assess a potential invasiveness degree of decapod crustaceans traded in Kazakhstan, we utilised the Freshwater Invertebrate Invasiveness Scoring Kit produced by the UK Centre for Environment, Fisheries and Aquaculture Science (FI-ISK, v.1.19, https://www.cefas.co.uk/services; Tricarico et al., 2010). Based on computed FI-ISK score, each evaluated species was subsequently classified as: (i) low (score $<1$ ); (ii) medium (score $\geq 1$ but $<16$ ); and (iii) high (score $\geq 16$ ) from risk in target area perspective.

\section{Results}

In total, we recorded at least 16 species of decapod crustaceans pet-traded in Kazakhstan. This set contains 11 shrimp (8 from family Atyidae and 3 from family Palaemonidae), four crayfish (two from family Cambaridae and 2 from family Parastacidae), and one crab species (family Potamidae). The complete list of species and their current availability on market are given in Table 1. Since species identifications of some shrimps according to morphology were not clear, these taxa were not evaluated in risk assessment. Three species were found very common on the market accompanied by three common, five rare and two very rare species.

Climatic data showed the highest probability of establishment in two shrimps M. nipponense and P. modestus (score $\geq 8$ on entire target area) followed by shrimps Neocaridina heteropoda and Caridina multidentata, crab Potamon potamios and crayfish Procambarus clarkii (wild and white morph) and $P$. fallax $\mathrm{f}$. virginalis.

The FI-ISK score ranged between values of -2 and 30 . Two shrimp species were assessed as low-risk, seven shrimp species, one crayfish and the crab were classified as mediumrisk, and three crayfish were classified in high-risk category (Tab. 1). The probability of establishment of the high-risk species, crayfish $C$. destructor, $P$. clarkii, and $P$. fallax $\mathrm{f}$. virginalis, within Kazakhstan territory is shown in Figure 1. 


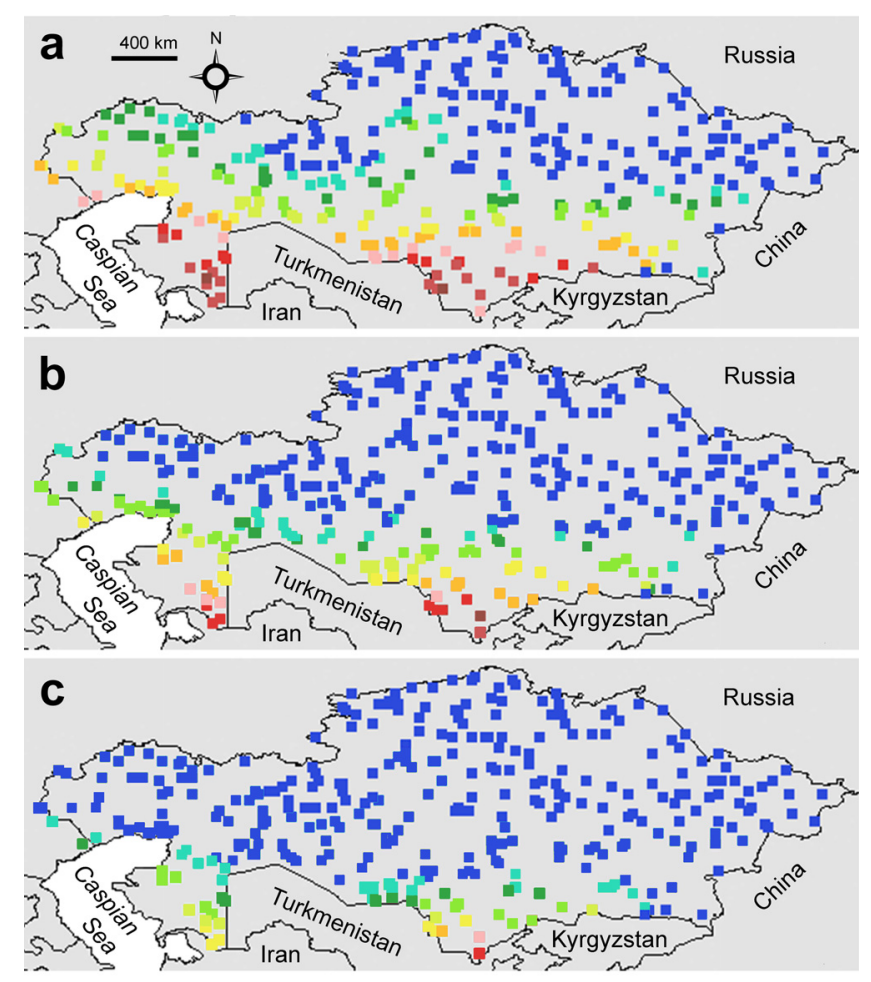

$\begin{array}{lllllllllll}0 & 1 & 2 & 3 & 4 & 5 & 6 & 7 & 8 & 9 & 10\end{array}$

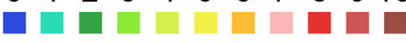

Fig. 1. Climate match map of Kazakhstan showing colour-coded regions with a different probability of establishment of the most hazardous from all evaluated species: (a) marbled crayfish (Procambarus fallax f. virginalis), (b) red swamp crayfish (Procambarus clarkii), and (c) yabby (Cherax destructor); scores of $\geq 7.0$ are interpreted as there is no environmental barrier to survival.

\section{Discussion}

All ornamental decapod crustaceans found pet-traded in Kazakhstan are non-native in this landlocked country. Since we recorded collection of at least 16 species (Tab. 1), it is obvious that the pet trade with these animals is probably welldeveloped and popular in more countries than were previously overlooked in this regard.

The majority of found pet-traded species are adapted to the freshwater environment within their entire life cycle (Tropea et al., 2015). However shrimp C. multidentata and two fan shrimps, Atya gabonensis and Atyopsis moluccensis, live in freshwaters in adulthood only and their free-living larvae require brackish water for successful development (Page et al., 2008) (Tab. 1). Although Kazakhstan has no connection with ocean, larvae of $M$. nipponense can tolerate brackish conditions in the Caspian Sea with salinity circa 10-13 g/L (De Grave and Ghane, 2006). Hence we assume that, in the case of mentioned shrimp species, there is no barrier to their larval development and survival in Kazakhstan in this regard.

Probably the most important climatic factor affecting the survival of decapod crustaceans is temperature (Hartnoll, 2001). Aforementioned fan shrimps are not capable of acclimating to climatic conditions in Kazakhstan. Based on evaluated climatic matching, we identified as species with the highest probability of establishment two shrimps $M$. nipponense and $P$. modestus, both species previously introduced in Kazakhstan (De Grave and Ghane, 2006; De Grave and Mann, 2012). These species are followed to a lesser extent shrimps $N$. heteropoda and C. multidentata, crab P. potamios, and crayfish $P$. fallax f. virginalis (Fig. 1a) and P. clarkii (Fig. 1b). The climatic matching of the rest of recorded species was very low. From these species, two shrimps, C. multidentata and $N$. heteropoda, are very common on the market following by common crayfish $P$. fallax $\mathrm{f}$. virginalis. Availability on market is highly comparable with the situation in other countries (Faulkes, 2015b; Lipták and Vitázková, 2015; Patoka et al., 2015). The origin of traded decapods in Kazakhstan is unclear. Nevertheless, the market is probably saturated by exports from Russia similarly as could be in Ukraine (Kotovska et al., 2016), but imports from China and South-Eastern Asia are also expected. Domestic production of some easily bred species such shrimp $N$. heteropoda and crayfish $P$. fallax f. virginalis is also possible.

In comparison with previously analysed markets in European countries (e.g. Chucholl, 2013; Patoka et al., 2015; Kotovska et al., 2016) and in the USA (Faulkes, 2015b), no crayfish species from genera Cambarellus were found traded in Kazakhstan. Since some of these species such as Cambarellus patzcuarensis are very common on mentioned markets, their absence in Kazakhstan suggests that the pet trade with crayfish is still developing with a probable increase in the number of traded species in near future. Also other colour morphs of $P$. clarkii such as full red, blue, orange and ghost are prospective in this regard.

Faulkes (2015a) mentioned two major threats for native decapods caused by pet trade: the potential for overexploitation of native species and negative consequences related to non-native species releases and escapes. Currently, no native species has been found pet-traded in Kazakhstan, but expected a further increase in the number of traded species and growing popularity of their keeping may result into the exploiting of native crayfish as well. Considering risk assessment, the origin of particular species, their availability on the market, the probability of establishment and further aspects, we identified crayfish $P$. clarkii and P. fallax f. virginalis being the seriously hazardous taxa with high invasive potential within Kazakhstan territory. The origin of the latter was exclusively derived from aquarium-bred individuals since native populations of this species are not yet known (Martin et al., 2016). This crayfish reproduces exclusively unisexually (parthenogenetically) and thus a single female can theoretically establish a viable population that might outcompete native crayfish (Scholtz et al., 2003). Moreover, both mentioned species were confirmed to serve as a host and vector of the crayfish plague, the disease caused by the oomycete Aphanomyces astaci, which is almost lethal for both Kazakhstan native crayfish species (Keller et al., 2014; Mrugała et al., 2015; Svoboda et al., 2017). The adaptability to environmental changes like precipitation (Kouba et al., 2016) together with the lowtemperature tolerance (Veselý et al., 2015), and extremely fast growth and reproduction features (Vogt et al., 2004; SoutyGrosset et al., 2016) make these crayfish species to be "perfect invaders". This assumption has been confirmed by numerous examples of introduction and establishment in natural habitats. $P$. clarkii has been successfully introduced in all continents 
except Australia and Antarctica, e.g. it is recorded currently in 16 European countries (summarized in Gherardi, 2006; SoutyGrosset et al., 2016); and P. fallax f. virginalis established wild populations particularly in Germany (Chucholl et al., 2012), but it was also reported from Croatia (Samardžić et al., 2014), the Czech Republic (Patoka et al., 2016e), Hungary (Weiperth et al., 2015; Lökkös et al., 2016), Italy (Nonnis Marzano et al., 2009; Vojkovská et al., 2014), the Netherlands (Koese, 2008), Slovakia (Janský and Mutkovič, 2010; Lipták et al., 2016), Sweden (Bohman et al., 2013), Ukraine (Novitsky and Son, 2016), and outside of Europe in Madagascar (Jones et al., 2009; Kawai et al., 2009). Though salinity tolerance in P. fallax f. virginalis seems to be low, it is much higher in P. clarkii (Veselý et al., 2017 and references therein). This opens an issue of direct interactions even with stocks of native crayfish $A$. leptodactylus and A. pachypus in the Caspian Sea, the more that this region fulfil temperature requirements of both non-native crayfish (Vodovsky et al., 2017). Aforementioned facts have caused concern among local as well as international authorities which were consequently reflected in certain legislative restrictions such as the list of Invasive Alien Species of European Union Concern (EU Regulation No. 1143/2014; Commission Implementing Regulation No. 2016/1141). In case of found pet-traded Cherax species, C. quadricarinatus is not able to successfully overwinter under climatic conditions in Kazakhstan; and even if $C$. destructor can be perceived as hazardous species, its probability of establishment in the territory of Kazakhstan is also very limited (Fig. 1c).

Therefore, we highlight as necessary and crucial a further survey of lentic habitats near conurbations at least in Kazakhstan regions identified as threatened by the potential establishment of both $P$. clarkii and P. fallax f. virginalis. The attention should be focused especially on popular secondary habitats, such as gravel pit lakes, garden and park ponds where these crayfish are particularly released by hobbyists in other countries (e.g. Chucholl et al., 2012; Novitsky and Son, 2016; Souty-Grosset et al., 2016). If these crayfish will be found, stakeholders are strongly encouraged to initiate their eradication. To prevent new introductions, similarly as in the case of European Union, we recommend the total ban of import, trade and keeping of these high-risk taxa within Kazakhstan and adjoining countries in Central Asia.

Acknowledgements. This study was supported by the Internal Grant Agency of the Czech University of Life Sciences Prague "CIGA" (No. 20152007), and the Ministry of Education, Youth and Sports of the Czech Republic - projects "CENAKVA" (No. CZ.1.05/2.1.00/01.0024) and "CENAKVA II” (No. LO1205 under the NPU I program).

\section{References}

Alekhnovich A, Kulesh V. 2001. Variation in the parameters of the life cycle in prawns of the genus Macrobrachium Bate (Crustacea, Palaemonidae). Russ J Ecol 32: 420-425.

Aquiloni L, Becciolini A, Berti R, Porciani S, Trunfio C, Gherardi F. 2009. Managing invasive crayfish: use of X-ray sterilisation of males. Freshw Biol 54: 1510-1519.

Bohman P, Edsman L, Martin P, Scholtz G. 2013. The first Marmorkrebs (Decapoda: Astacida: Cambaridae) in Scandinavia. BioInvasions Rec 2: 227-232.
Chucholl C. 2013. Invaders for sale: trade and determinants of introduction of ornamental freshwater crayfish. Biol Invasions 15: $125-141$.

Chucholl C. 2014. Predicting the risk of introduction and establishment of an exotic aquarium animal in Europe: insights from one decade of Marmorkrebs (Crustacea, Astacida, Cambaridae) releases. Manag Biol Invasions 5: 309-318.

Chucholl C, Wendler F. 2016. Positive selection of beautiful invaders: long-term persistence and bio-invasion risk of freshwater crayfish in the pet trade. Biol Invasions 19: 197-208.

Chucholl C, Morawetz K, Groß H. 2012. The clones are coming-strong increase in Marmorkrebs [Procambarus fallax (Hagen, 1870) $\mathrm{f}$. virginalis] records from Europe. Aquat Invasions 7: 511-519.

De Grave S, Ghane A. 2006. The establishment of the oriental river prawn, Macrobrachium nipponense (de Haan, 1849) in Anzali Lagoon, Iran. Aquat Invasions 1: 204-208.

De Grave S, Mann DJ. 2012. The first record of Exopalaemon modestus (Heller, 1862) (Decapoda, Palaemonidae) in Kazakhstan. Crustaceana 85: 1665-1667.

Duggan IC. 2010. The freshwater aquarium trade as a vector for incidental invertebrate fauna. Biol Invasions 12: 3757-3770.

Faulkes Z. 2014. A bomb set to drop: parthenogenetic Marmorkrebs for sale in Ireland, a European location without non-indigenous crayfish. Manag Biol Invasions 6: 111-114.

Faulkes Z. 2015a. The global trade in crayfish as pets. Crustac Res 44: 75-92.

Faulkes Z. 2015b. Marmorkrebs (Procambarus fallax f. virginalis) are the most popular crayfish in the North American pet trade. Knowl Manag Aquat Ecosyst 416: 20.

Gherardi F. 2006. Crayfish invading Europe: the case study of Procambarus clarkii. Mar Freshw Behav Physiol 39: 175-191.

Gherardi F, Aquiloni L, Diéguez-Uribeondo J, Tricarico E. 2011. Managing invasive crayfish: is there a hope? Aquat Sci 73: 185-200.

Hartnoll RG. 2001. Growth in Crustacea-twenty years on. Hydrobiologia 449: 111-122.

Hassall C. 2014. The ecology and biodiversity of urban ponds. Wiley Interdiscip Rev: Water 1: 187-206.

Hijmans RJ, Cameron SE, Parra JL, Jones PG, Jarvis A. 2005. Very high resolution interpolated climate surfaces for global land areas. Int J Climatol 25: 1965-1978.

Isaev A, Karpova E. 1989. Reservoir fisheries [Рыбное хозяйство водохранилищ справочник]. Moscow: VO Agropromizdat.

Janský V, Mutkovič A. 2010. Rak Procambarus sp. (Crustacea: Decapoda: Cambaridae)-Prvy Nález na Slovensku. Zbornik Slovenského Národneho Múzea (Acta rerum naturalium Musei Nationalis Slovaci Bratislava) 56: 64-67.

Jones JP, Rasamy JR, Harvey A, et al. 2009. The perfect invader: a parthenogenic crayfish poses a new threat to Madagascar's freshwater biodiversity. Biol Invasions 11: 1475-1482.

Kawai T, Scholtz G, Morioka S, Ramanamandimby F, Lukhaup C, Hanamura Y. 2009. Parthenogenetic alien crayfish (Decapoda: Cambaridae) spreading in Madagascar. J Crustac Biol 29: 562-567.

Keller N, Pfeiffer M, Roessink I, Schulz R, Schrimpf A. 2014. First evidence of crayfish plague agent in populations of the marbled crayfish (Procambarus fallax forma virginalis). Knowl Manag Aquat Ecosyst 414: 15.

Kirichenko OI, Zharkenov DK, Anuarbekov CM. 2013. Current status of the populations and the degree of the development of crayfish stocks in the Irtysh basin reservoirs [Современное состояние популяций и степень освоения запасов речного рака в водоемах Иртышского бассейна]. Altai - Golden Cradle of Turkic World [Алтай - золотая колыбель тюркского мира] $85-90$. 
Klotz W, Miesen FW, Hüllen S, Herder F. 2013. Two Asian fresh water shrimp species found in a thermally polluted stream system in North Rhine-Westphalia, Germany. Aquat Invasions 8: 333-339.

Koese B. 2008. Rivierkreeften proeftabel. Leiden: Naturalis.

Kotovska G, Khrystenko D, Patoka J, Kouba A. 2016. East European crayfish stocks at risk: arrival of non-indigenous crayfish species. Knowl Manag Aquat Ecosyst 417: 37.

Kouba A, Petrusek A, Kozák P. 2014. Continental-wide distribution of crayfish species in Europe: update and maps. Knowl Manag Aquat Ecosyst 413: 05.

Kouba A, Tíkal J, Císař P, et al. 2016. The significance of droughts for hyporheic dwellers: evidence from freshwater crayfish. Sci Rep 6: 26569.

Kwon C, Uno Y. 1968. The larval development of Palaemon modestus (Heller) in the laboratory. La Mer 6: 31-46.

Lipták B, Vitázková B. 2015. Beautiful, but also potentially invasive. Ekológia (Bratislava) 34: 155-162.

Lipták B, Mrugała A, Pekárik L, et al. 2016. Expansion of the marbled crayfish in Slovakia: beginning of an invasion in the Danube catchment? J Limnol 75: 305-312.

Lőkkös A, Müller T, Kovács K, Várkonyi L, Specziár A, Martin P. 2016. The alien, parthenogenetic marbled crayfish (Decapoda: Cambaridae) is entering Kis-Balaton (Hungary), one of Europe's most important wetland biotopes. Knowl Manag Aquat Ecosyst 417: 16.

Magalhães C, Bueno SLS, Bond-Buckup G, et al. 2005. Exotic species of freshwater decapod crustaceans in the state of São Paulo, Brazil: records and possible causes of their introduction. Biodivers Conserv 14: 1929-1945.

Malinovskaia A. 1984. River crayfish in Kazakhstan [Речные раки в Казахстане]. Akademiia nauk Kazakhskoi SSR, Trudy Institut Zoologii [Академия Наук Казахской ССР, Труды Института Зоологии] 41: 101-107.

Mamilov NS. Biology of Balkhash Perch (Perca schrenkii Kessler, 1874). In: Couture P, Pyle G, eds. Biology of perch. Boca Raton, London, New York: CRC Press, 2015.

Martin P, Thonagel S, Scholtz G. 2016. The parthenogenetic Marmorkrebs (Malacostraca: Decapoda: Cambaridae) is a triploid organism. J Zool Syst Evol Res 54: 13-21.

Mashiko K. 1990. Diversified egg and clutch sizes among local populations of the fresh-water prawn Macrobrachium nipponense (De Haan). J Crustac Biol 10: 306-314.

Mazza G, Aquiloni L, Inghilesi AF, et al. 2015. Aliens just a click away: the online aquarium trade in Italy. Manag Biol Invasions 6: 253-261.

Mirabdullaev I, Niyazov D. 2005. Alien decapods (Crustacea) in Uzbekistan. II. International Symposium Invasion of alien species in Holarctic. Russia: Borok.

Mrugała A, Kozubíková-Balcarová E, Chucholl C, et al. 2015. Trade of ornamental crayfish in Europe as a possible introduction pathway for important crustacean diseases: crayfish plague and white spot syndrome. Biol Invasions 17: 1313-1326.

Nonnis Marzano F, Scalici M, Chiesa S, Gherardi F, Piccinini A, Gibertini G. 2009. The first record of the marbled crayfish adds further threats to fresh waters in Italy. Aquat Invasions 4: 401-404.

Novitsky RA, Son MO. 2016. The first records of Marmorkrebs [Procambarus fallax (Hagen, 1870) f. virginalis] (Crustacea, Decapoda, Cambaridae) in Ukraine. Ecol Montenegrina 5: 44-46.

Padilla DK, Williams SL. 2004. Beyond ballast water: aquarium and ornamental trades as sources of invasive species in aquatic ecosystems. Front Ecol Environ 2: 131-138.

Page TJ, Cook BD, von Rintelen T, von Rintelen K, Hughes JM. 2008. Evolutionary relationships of atyid shrimps imply both ancient
Caribbean radiations and common marine dispersals. $J N \mathrm{Am}$ Benthol Soc 27: 68-83.

Papavlasopoulou I, Perdikaris C, Vardakas L, Paschos I. 2014. Enemy at the gates: introduction potential of non-indigenous freshwater crayfish in Greece via the aquarium trade. Cent Eur J Biol 9: 1-8.

Patoka J, Kalous L, Kopecký O. 2014a. Risk assessment of the crayfish pet trade based on data from the Czech Republic. Biol Invasions 16: 2489-2494.

Patoka J, Petrtýl M, Kalous L. 2014b. Garden ponds as potential introduction pathway of ornamental crayfish. Knowl Manag Aquat Ecosyst 414: 13.

Patoka J, Kalous L, Kopecký O. 2015. Imports of ornamental crayfish: the first decade from the Czech Republic's perspective. Knowl Manag Aquat Ecosyst 416: 04.

Patoka J, Bláha M, Devetter M, Rylková K, Čadková Z, Kalous L. 2016a. Aquarium hitchhikers: attached commensals imported with freshwater shrimps via the pet trade. Biol Invasions 18: 457-461.

Patoka J, Bláha M, Kalous L, Kouba A. 2016b. Irresponsible vendors: non-native, invasive and threatened animals offered for stocking garden ponds. Aquat Conserv, doi:10.1002/aqc.2719.

Patoka J, Bláha M, Kalous L, Vrabec V, Buřič M, Kouba A. 2016c. Potential pest transfer mediated by international ornamental plant trade. Sci Rep 6: 25896.

Patoka J, Wardiatno Y, Yonvitner, Kuř́ková P, Petrtýl M, Kalous L. 2016d. Cherax quadricarinatus (von Martens) has invaded Indonesian 1 territory west of the Wallace Line: evidences from Java. Knowl Manag Aquat Ecosyst417: 39.

Patoka J, Buřič M, Kolář V, et al. 2016e. Predictions of marbled crayfish establishment in conurbations fulfilled: evidences from the Czech Republic. Biologia 71: 1380-1385.

Peay S. 2009. Invasive non-indigenous crayfish species in Europe: recommendations on managing them. Knowl Manag Aquat Ecosyst 394-395: 03.

Pomfret RW. 2006. The Central Asian economies since independence. New Jersey: Princeton University Press.

Samardžić M, Lucić A, Maguire I, Hudina S. 2014. The first record of the marbled crayfish (Procambarus fallax (Hagen, 1870) f. virginalis) in Croatia. Crayfish News 36: 4.

Scholtz G, Braband A, Tolley L, et al. 2003. Parthenogenesis in an outsider crayfish. Nature 421: 806.

Soes DM, Koese B. 2010. Invasive crayfish in the Netherlands: a preliminary risk analysis. Waardenburg, The Netherlands: EISNederland and Bureau Waardenburg.

Souty-Grosset C, Anastácio PM, Aquiloni L, et al. 2016. The red swamp crayfish Procambarus clarkii in Europe: impacts on aquatic ecosystems and human well-being. Limnologica 58: 78-93.

Svoboda J, Mrugała A, Kozubíková-Balcarová E, Petrusek A. 2017. Hosts and transmission of the crayfish plague pathogen Aphanomyces astaci: a review. J Fish Dis 40: 127-140.

Takenov Z, Panchenko N, Kim S, Sarsembekov T, Mirkhashimov I. 2004. Water resources of Kazakhstan in the new millennium. Almaty, Republic of Kazakhstan: United Nations Development Programme.

Tlusty MF, Rhyne AL, Kaufman L, et al. 2013. Opportunities for public aquariums to increase the sustainability of the aquatic animal trade. Zoo Biol 32: 1-12.

Tricarico E, Vilizzi L, Gherardi F, Copp GH. 2010. Calibration of FIISK, an invasiveness screening tool for nonnative freshwater invertebrates. Risk Anal 30: 285-292.

Tropea C, Stumpf L, Greco LSL. 2015. Effect of temperature on biochemical composition, growth and reproduction of the ornamental red cherry shrimp Neocaridina heteropoda heteropoda (Decapoda, Caridea). PLOS ONE 10: e0119468. 
T. Uderbayev et al.: Knowl. Manag. Aquat. Ecosyst. 2017, 418, 30

Turkmen G, Karadal O. 2012. The survey of the imported freshwater decapod species via the ornamental aquarium trade in Turkey. $J$ Anim Vet Adv 11: 2824-2827.

Veselý L, Buřič M, Kouba A. 2015. Hardy exotics species in temperate zone: can "warm water" crayfish invaders establish regardless of low temperatures? Sci Rep 5: 16340.

Veselý L, Hrbek V, Kozák P, Buřič M, Sousa R, Kouba A. 2017. Salinity tolerance of marbled crayfish Procambarus fallax $\mathrm{f}$. virginalis. Knowl Manag Aquat Ecosyst 418: 21.

Vodovsky N, Patoka J, Kouba A. 2017. Ecosystem of Caspian Sea threatened by pet-traded non-indigenous crayfish. Biol Invasions, doi:10.1007/s10530-017-1433-1.
Vogt G, Tolley L, Scholtz G. 2004. Life stages and reproductive components of the Marmorkrebs (marbled crayfish), the first parthenogenetic decapod crustacean. J Morphol 261: 286-311.

Vojkovská R, Horká I, Tricarico E, Duriš Z. 2014. New record of the parthenogenetic marbled crayfish Procambarus fallax f. virginalis from Italy. Crustaceana 87: 1386-1392.

Weiperth A, Csányi B, Gál B, et al. 2015. Egzotikus rák-, hal- és kétéltűfajok a Budapest környéki víztestekben [Exotic crayfish, fish and amphibian species in various water bodies in the region of Budapest]. Pisces Hungarici 9: 65-70.

Cite this article as: Uderbayev T, Patoka J, Beisembayev R, Petrtýl M, Bláha M, Kouba A. 2017. Risk assessment of pet-traded decapod crustaceans in the Republic of Kazakhstan, the leading country in Central Asia. Knowl. Manag. Aquat. Ecosyst., $418,30$. 